\title{
Detection and Isolate Differentiation of Citrus tristeza virus in Infected Field Trees Based on Reverse Transcription-Polymerase Chain Reaction
}

Zhipeng Huang, Biotechnology Center, College of Life Science, Fujian Agriculture \& Forestry University, Fuzhou, Fujian 350002 P. R. China; Phyllis A. Rundell, Biologist, Indian River Research and Education Center, University of Florida, Fort Pierce 34945; Xiong Guan, Biotechnology Center, College of Life Science, Fujian Agriculture \& Forestry University, Fuzhou, Fujian 350002 P. R. China; and Charles A. Powell, Professor, Indian River Research and Education Center, University of Florida, Fort Pierce 34945

\begin{abstract}
Huang, Z., Rundell, P. A., Guan, X., and Powell, C. A. 2004. Detection and isolate differentiation of Citrus tristeza virus in infected field trees based on reverse transcription-polymerase chain reaction. Plant Dis. 88:625-629.

Reverse transcription-polymerase chain reaction (RT-PCR) was compared with enzyme-linked immunosorbent assay (ELISA) and direct tissue blot immunoassay (DTBIA) for detection of non-decline-inducing and decline-inducing isolates of Citrus tristeza virus (CTV) in 21 field sweet orange and grapefruit plants on sour orange rootstock in Fort Pierce, FL. Among these samples, seven, six, and eight were infected with decline-inducing, non-decline-inducing, and both decline-inducing and non-decline-inducing isolates of CTV, respectively. However, there was not a good correlation between field symptoms and detection of the decline-inducing isolate. The results confirmed that RT-PCR is not only able to detect and differentiate declineinducing and non-decline-inducing isolates of CTV in Florida, but also can detect both isolate types in a single field sweet orange or grapefruit tree. For most samples, results from RT-PCR, ELISA, and DTBIA were the same. However, the 320-bp fragments produced only from declineinducing isolates were amplified from two sweet orange and two grapefruit samples that did not react with decline-inducing CTV-specific monoclonal antibody MCA13 in ELISA or DTBIA, indicating that RT-PCR has a higher sensitivity than these immunological tests for field sweet orange or grapefruit samples. Thus, RT-PCR is a simple, rapid, and specific procedure for CTV identification applicable to both research and diagnostic needs.
\end{abstract}

Additional keywords: cross-protection, diagnosis

Citrus tristeza virus (CTV), a member of the genus Closterovirus of the Closteroviridae, is distributed worldwide and is the causal agent of one of the most economically important diseases of citrus $(3,4)$. Virus particles are flexuous, threadlike, and 2,000 $\mathrm{nm}$ in length and 10 to $12 \mathrm{~nm}$ in diameter (4). The single-stranded RNA genome of CTV is about $20 \mathrm{~kb}$ and contains 12 open reading frames (ORFs) that potentially encode at least 19 proteins $(16,17)$. The virus is genetically and biologically diverse and can cause stunting, slow decline, quick decline, stem pitting, or no symptoms depending on the virus isolate, time of infection, rootstock, citrus cultivar, and environmental conditions $(10,21)$. Decline isolates kill citrus trees on sour orange or related rootstock, and stem pitting isolates make citrus production

Corresponding author: Charles A. Powell

E-mail: capowell@mail.ifas.ufl.edu

Florida Agriculture Experiment Station Journal Series R-09736.

Accepted for publication 29 December 2003.

Publication no. D-2004-0319-01R

(C) 2004 The American Phytopathological Society uneconomical because of poor tree vigor and small fruit. During the last century, CTV has devastated entire citrus industries in several countries (2).

Measures to control losses caused by CTV include quarantine systems to avoid introduction of exotic isolates, certification programs to prevent CTV spread, and cross-protection with mild isolates (27). These measures require rapid procedures to detect CTV and to discriminate between mild and severe isolates. Isolates of CTV that induced different field symptoms were traditionally differentiated by inoculating the appropriate indicator plants and observing the symptoms. This bioassay was time-consuming, expensive, and often imprecise. In recent years, remarkable progress in the development of quick, accurate techniques for the detection and differentiation of isolates of CTV has been achieved (22). These techniques involved SDS-Immunodiffusion $(3,5,9)$, direct tissue blot immunoassay (DTBIA) (11), restriction fragment length polymorphism (RFLP) (12), serologically specific electron microscope (SSEM) (5), enzymelinked immunosorbent assay (ELISA) $(3,7,23,26)$, dot-immunobinding assay $(28,29)$, radio-immunosorbent assay (RISA) (26), in situ immunofluorescence
(ISIF) (6), in situ immunoassay (ISIA) (19), Western blot assay $(13,18,26)$, singlestrand conformation polymorphism (SSCP) (30), and reverse transcriptionpolymerase chain reaction (RT-PCR) $(8,15,20)$. In this study, RT-PCR has been applied for detection and differentiation of the non-decline-inducing and declineinducing isolates of CTV in infected field trees in Florida, as well as for detection of both isolate types in mixed infections. The purpose was to test the usefulness of this technique and to probe the relationship between field symptoms and detection of decline-inducing isolates in different varieties of citrus. Moreover, this technique was also compared with immunological techniques for field diagnosis of CTV. The information will be helpful for the development of field detection systems for CTV.

\section{MATERIALS AND METHODS}

Virus isolates and plant materials. Four isolates of CTV, maintained in the greenhouse at the Indian River Research and Education Center, Fort Pierce, FL, were used to standardize the procedure of RT-PCR. The biological characteristics of the isolates were described previously (19). Field samples were from 14 sweet orange trees on sour orange rootstock (SSO) and 7 grapefruit trees on sour orange rootstock (GF) at the Indian River Research and Education Center. All the sweet orange trees were declining, whereas the grapefruit trees were not declining. The mature shoots of citrus plants were collected from east, west, south, and north locations and mixed for the tests. Stems of shoots were used for DTBIA and the extraction of nucleic acid for RT-PCR. Petioles of the same shoots were used to prepare extractions for ELISA experiments.

ELISA. Indirect double antibody sandwich (I-DAS) ELISA (3) was performed to diagnose citrus trees infected by CTV. One polyclonal antiserum (PCA) 1212 and two monoclonal antibodies (MAbs), 17G11 and MCA13, were used in this study. Their characteristics were described previously (19). The IgG of PCA 1212 was used as coating antibody, and the two others were used as intermediate antibodies. Extractions were prepared for ELISA from $0.5 \mathrm{~g}$ of petioles with $5 \mathrm{ml}$ of $1 \times$ PBST buffer $\left(0.15 \mathrm{M} \mathrm{NaCl}, 0.015 \mathrm{M} \mathrm{NaH}_{2} \mathrm{PO}_{4}, 0.05 \%\right.$ 
Tween 20, pH 7.0). Positive reactions were defined as an $\mathrm{OD}_{415 \mathrm{~nm}} 2$ times higher than the healthy control.

DTBIA. Direct tissue blot immunoassay (11) was also performed on stems of healthy or infected citrus plants. A smooth fresh cut was made with a razor blade, and the cut surface was pressed gently and evenly to the nitrocellulose membrane (Bio-Rad Laboratories, Hercules, CA). The blotted membranes were allowed to dry for 10 to $30 \mathrm{~min}$, incubated in plastic bags with MAb 17 G11 or MCA13 for $2 \mathrm{~h}$ at $37^{\circ} \mathrm{C}$, and rinsed with PBST buffer three times ( $3 \mathrm{~min}$ each time). The blots were labeled with alkaline phosphatase conjugated goat antimouse $\mathrm{Ig}(\mathrm{H}+\mathrm{L})-\mathrm{Ap}$ at a 1:2,000 dilution for 1 to $2 \mathrm{~h}$ at $37^{\circ} \mathrm{C}$, rinsed with PBST-PVP (PBST with $2 \%$ polyvinylpyrrolidone) three times $(3 \mathrm{~min}$ each time), and then incubated in a petri dish with the freshly prepared substrate mixture of nitro-blue tetrazolium (NBT) and 5bromo-4-chloro-3-indolyl phosphate (BCIP) for 5 to $20 \mathrm{~min}$ to develop the reaction. After stopping the reaction by washing the blots with water, the blots were observed under a light microscope at $\times 10$ magnification. A positive reaction was the development of a purple color in the phloem tissue. Blots where no purple color developed were considered negative.

Nucleic acid extraction from citrus tissues. Total nucleic acid extracts of samples were used as templates for RT-PCR. The extraction procedure as described by Hung et al. (15) was modified slightly and used in this study. In short, stems (approximately $250 \mathrm{mg}$ ) were placed in a canister and pulverized with liquid nitrogen for 40 s using a KLECO Model 4200 Pulverizer (Kinetic Laboratory Equipment Company, Visalia, CA) and then collected into a 1.5-ml sterile Eppendorf tube. Each sample was suspended in nucleic acid extraction buffer (0.1 M Tris- $\mathrm{HCl}$ [pH 8.0], $0.05 \mathrm{M}$ EDTA, $0.5 \mathrm{M} \mathrm{NaCl}, 1 \% \mathrm{~N}$ lauroylsarcosine) and incubated at $55^{\circ} \mathrm{C}$ for $1 \mathrm{~h}$. After centrifugation $(6,000 \mathrm{rpm})$ for $5 \mathrm{~min}$, the supernatant $(800 \mu \mathrm{l})$ was treated with $100 \mu \mathrm{l}$ of $5 \mathrm{M} \mathrm{NaCl}$ and $100 \mu \mathrm{l}$ of $10 \%$ hexadecyl-trimethyl-ammoniumbromide $(\mathrm{CTAB})$ at $65^{\circ} \mathrm{C}$ for $10 \mathrm{~min}$ and then extracted with chloroform/isoamyl alcohol (24:1). The aqueous supernatant was re-extracted with phenol/chloroform/isoamyl alcohol $(25: 24: 1)$. The nucleic acid was precipitated from the aqueous layer with 0.6 volume of isopropanol at room temperature for $15 \mathrm{~min}$. The pellet was collected by centrifugation at 12,000 rpm for $10 \mathrm{~min}$ and washed with $70 \%$ ethanol, dried, and resuspended in $20 \mu \mathrm{l}$ TE buffer (pH 8.0).

Primers. Two internal primers, one $\left(\mathrm{CP}_{4}\right)$ specific for non-decline-inducing $\left(\mathrm{T}_{30}\right)$ and the other $\left(\mathrm{CP}_{3}\right)$ specific for decline-inducing isolates $\left(\mathrm{T}_{36}\right)$ of $\mathrm{CTV}$, and two terminal primers $\left(\mathrm{HCP}_{1}\right.$ and $\left.\mathrm{HCP}_{2}\right)$ for the ends of the capsid protein gene were designed on the basis of the reported studies by Cevik et al. (8) and the published nucleotide sequence of CTV isolates $\mathrm{T}_{36}$ and $\mathrm{T}_{30}(2,17)$. The characterization of primers is described in Table 1.

cDNA synthesis and polymerase chain reaction amplification. The first-strand cDNA was synthesized using total nucleic acid extracted from citrus stems as templates and $\mathrm{HCP}_{2}, \mathrm{CP}_{4}$ as the primers. The total reaction volume was $20 \mu \mathrm{l}$, which contained $50 \mathrm{mM}$ Tris- $\mathrm{HCl}(\mathrm{pH} 8.3), 75$ $\mathrm{mM} \mathrm{KCl}, 3 \mathrm{mM} \mathrm{MgCl}$, $10 \mathrm{mM}$ DTT, 0.5 $\mathrm{mM}$ each of the four dNTPs, $0.75 \mu \mathrm{M}$ of primer $\mathrm{HCP}_{2}, 0.75 \mu \mathrm{M}$ of primer $\mathrm{CP}_{4}, 100$ units of SuperScript II RNase H- Reverse Transcriptase (Invitrogen, Carlsbad, CA), 40 units RNaseOUT Recombinant Ribonuclease Inhibitor (Invitrogen), and $8 \mu \mathrm{l}$ of nucleic acid extract. The contents were mixed gently and incubated at $42^{\circ} \mathrm{C}$ for 50 min. The PCR amplification was performed in $50 \mu \mathrm{l}$ of reaction mixture containing $20 \mathrm{mM}$ Tris- $\mathrm{HCl}$ (pH 8.4), $50 \mathrm{mM}$ $\mathrm{KCl}, 0.2 \mathrm{mM}$ each of the four dNTPs, 1.5 $\mathrm{mM} \mathrm{MgCl} 2,0.5 \mu \mathrm{M}$ primer $\mathrm{HCP}_{1}, 0.5 \mu \mathrm{M}$ primer $\mathrm{HCP}_{2}, 0.5 \mu \mathrm{M}$ of primer $\mathrm{CP}_{3}, 0.5$ $\mu \mathrm{M}$ of primer $\mathrm{CP}_{4}, 2.5$ units of Taq DNA polymerase (Invitrogen), and 2 to $2.5 \mu \mathrm{l}$ of RT mixture. The PCR cycling profile was one cycle at $94^{\circ} \mathrm{C}$ for $10 \mathrm{~min}$, followed by 35 cycles of $94^{\circ} \mathrm{C}$ for $1 \mathrm{~min}, 50^{\circ} \mathrm{C}$ for 2 min, and $72^{\circ} \mathrm{C}$ for $2 \mathrm{~min}$, with a final extension step at $72^{\circ} \mathrm{C}$ for $20 \mathrm{~min}$. Aliquots of PCR-amplified fragments were electrophoresed in $2 \%$ agarose gels in Tris-borate (TBE) buffer (0.09 M Tris base, $0.09 \mathrm{M}$ boric acid, $0.002 \mathrm{M}$ EDTA, $\mathrm{pH}$ 8.0). After electrophoresis, the gels were stained with ethidium bromide at $0.5 \mu \mathrm{g} / \mathrm{ml}$ and then analyzed using a BIO imaging system (Syngene, Frederick, MD). A 100-bp DNA Ladder (Promega, Madison, WI) was used as a nucleic acid marker.

\section{RESULTS}

Detection and isolate differentiation of the known CTV isolates by RT-PCR.
Different amplified fragments of different isolate types were obtained by using $\mathrm{HCP}_{1}$, $\mathrm{HCP}_{2}, \mathrm{CP}_{3}$, and $\mathrm{CP}_{4}$ as primers and nucleic acids as templates (Fig. 1). For nondecline-inducing isolates $\left(\mathrm{T}_{26}\right.$ and $\left.\mathrm{T}_{30}\right)$, a 672-bp full-length CP gene fragment and a 392-bp fragment were produced (Fig. 1, lanes 3 and 4). The 672- and 320-bp fragments were amplified from declineinducing isolates $\left(\mathrm{T}_{3}\right.$ and $\mathrm{T}_{36}$ ) (Fig. 1, lanes 5,6 , and 7). From the infection with both decline-inducing and non-decline-inducing isolates $\left(\mathrm{T}_{30}+\mathrm{T}_{36}\right)$, the 672-, 392-, and 320-bp fragments were all produced (Fig. 1, lane 8). No fragment was obtained from the healthy tissue extract (Fig. 1, lane 2).

Detection and isolate differentiation of CTV in infected field samples by RTPCR. RT-PCR was applied to test 21 CTVinfected field samples from sweet orange and grapefruit plants on sour orange rootstock (Figs. 2 and 3). Decline-inducing isolate $\mathrm{T}_{36}$, non-decline-inducing isolate $\mathrm{T}_{30}$, artificial mixtures of $\mathrm{T}_{36}$ and $\mathrm{T}_{30}$, and a healthy sample were used as positive and negative controls. The 672-, 392-, and 320bp fragments were amplified from eight of these samples, indicating that they were infected with both decline-inducing and non-decline-inducing isolates of CTV (Fig. 2A, lanes 6 and 11; Fig. 2B, lanes 7, 8, 9, 10, and 11; Fig. 3, lane 10). From seven of these samples, the 672- and 320-bp fragments were produced, indicating that they were infected only with decline-inducing isolates of CTV (Fig. 2A, lane 7; Fig. 2B,

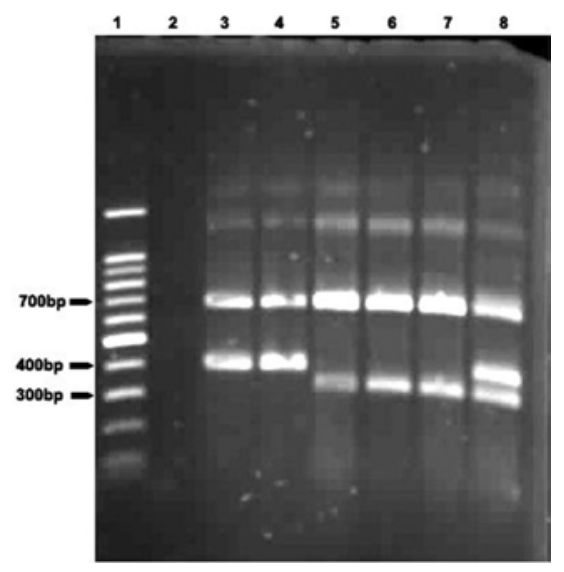

Fig. 1. Analysis of reverse transcriptionpolymerase chain reaction (RT-PCR) products of the known isolates of Citrus tristeza virus (CTV). Lane 1: 100-bp DNA ladder; lane 2: extract of healthy plant; lane $3: \mathrm{T}_{26} ;$ lane $4: \mathrm{T}_{30}$; lane $5: \mathrm{T}_{3}$; lane 6: $\mathrm{T}_{36}$; lane 7: $\mathrm{T}_{36}$; lane $8: \mathrm{T}_{30}+\mathrm{T}_{36}$.

Table 1. Primers used for reverse transcription-polymerase chain reaction (RT-PCR) to detect and differentiate isolates of Citrus tristeza virus (CTV)

\begin{tabular}{|c|c|c|c|c|c|}
\hline Primers & Polarity & Sequence & Position $^{\mathrm{a}}$ & $\operatorname{Tm}\left({ }^{\circ} \mathbf{C}\right)$ & Predicted product size ${ }^{b}$ \\
\hline $\mathrm{HCP}_{1}$ & + & 5'-ATGGACGACGAAACAAAGAA-3' & $16155-16174$ & 56 & 672 bp \\
\hline $\mathrm{HCP}_{2}$ & - & 5'-TCAACGTGTGTTGAATTTCC-3' & $16826-16807$ & 56 & $672 \mathrm{bp}$ \\
\hline $\mathrm{CP}_{3}$ & + & 5'-TTTGGACTGACGTCGTGTT-3' & $16507-16525$ & 56 & $320 \mathrm{bp}$ \\
\hline $\mathrm{CP}_{4}$ & - & 5'-TTACCAATACCCTTAGAATTAT-3' & $16546-16525$ & 56 & 392 bp \\
\hline
\end{tabular}

a Nucleotide position of primers in sequence of CTV isolates $\mathrm{T}_{36}$.

${ }^{b}$ 672-bp fragment is the product of primer pair $\mathrm{HCP}_{1}$ and $\mathrm{HCP}_{2} .320$-bp fragment is the product of primer pair $\mathrm{CP}_{3}$ and $\mathrm{HCP}$. $392-\mathrm{bp}$ fragment is the product of primer pair $\mathrm{HCP}_{1}$ and $\mathrm{CP}_{4}$. 
lanes 6 and 12; Fig. 3, lanes 6, 8, 9, and 11). From the rest of these samples, the 672- and 392-bp fragments were produced, indicating that they were infected only with non-decline-inducing isolates of CTV (Fig. 2A, lanes 5, 8, 9, and 10; Fig. 3, lanes 7 and 12).

Comparison of DTBIA, ELISA, and RT-PCR. Twenty-one CTV-infected field samples were also tested by DTBIA and ELISA with MAb 17G11 and MCA13. A comparison of the results of DTBIA, ELISA, and RT-PCR is shown in Table 2. RT-PCR results of most samples were consistent with those obtained with DTBIA and ELISA. However, the 320-bp fragments were amplified from samples SSO-3, SSO-7, GF-5, and GF-6, indicating that they were infected with declineinducing isolates of CTV, even though they were MCA13-negative in ELISA or DTBIA.

\section{DISCUSSION}

With the development of polyclonal antisera and monoclonal antibodies, serological methods have become a dependable tool for CTV detection and isolate differentiation. Among antibodies, MCA13 is especially useful because it reacts with most severe isolates. This positive reaction has been associated with tree decline in
Florida (22). Thus, MCA13 is now commonly used as a first step for differentiation of decline-inducing and non-declineinducing isolates of CTV in Florida. It had been demonstrated by site-directed mutagenesis that the epitope for MCA13 is based on a single nucleotide difference at position 371 of the capsid protein gene, mostly being $\mathrm{T}$ for severe isolates and $\mathrm{A}$ for mild isolates (24). Based on this characteristic, two internal primers (CN218 and $\mathrm{CN} 219$ ) and two terminal primers (CN119 and CN120) were designed by Cevik et al. (8) and used for differentiating CTV isolates. In this study, the two inter-

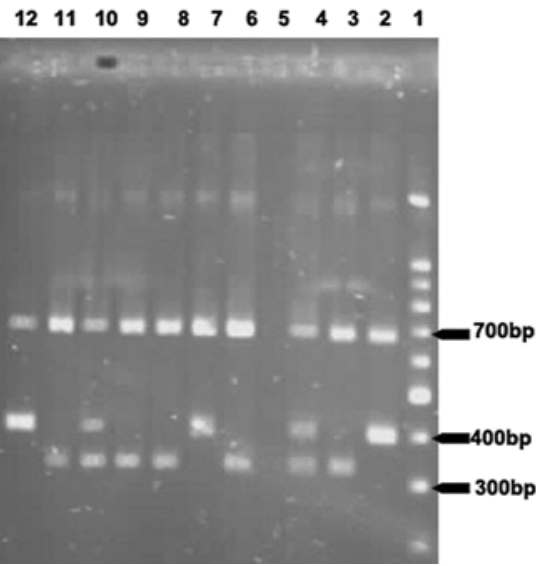

Fig. 3. Analysis of reverse transcriptionpolymerase chain reaction (RT-PCR) products of Citrus tristeza virus (CTV)-infected field samples from grapefruit trees on sour orange rootstock. Lane 1: 100-bp DNA ladder; lane 2: $\mathrm{T}_{30}$; lane 3: $\mathrm{T}_{36} ;$ lane 4: $\mathrm{T}_{30}+\mathrm{T}_{36}$; lane 5: extract of healthy plant; lane 6: GF-1; lane 7: GF-2; lane 8: GF-3; lane 9: GF-4; lane 10: GF-5; lane 11: GF-6; lane 12: GF-7.
Fig. 2. Analysis of reverse transcription-polymerase chain reaction (RT-PCR) products of Citrus tristeza virus (CTV)-infected field samples from sweet orange trees on sour orange rootstock. A, lan 1. 100-bp DNA ladder; lane 2: $\mathrm{T}_{30}$; lane 3: $\mathrm{T}_{36} ;$ lane 4: $\mathrm{T}_{30}+\mathrm{T}_{36} ;$ lane 5: SSO-1; lane 6: $\mathrm{SSO}-2$, lane 7: SSO-3; lane 8: SSO-4; lane 9: SSO-5; lane 10: SSO-6; lane 11: SSO-7; lane 12: extract of heatt plant. B, lane 1: 100-bp DNA ladder; lane 2: extract of healthy plant; lane $3: \mathrm{T}_{30}$; lane $4: \mathrm{T}_{36}$; lane 5 : $\mathrm{T}_{30}+\mathrm{T}_{36}$; lane 6: SSO-8; lane 7: SSO-9; lane 8: SSO-10; lane 9: SSO-11; lane 10: SSO-12; lane 11 SSO-13; lane 12: SSO-14.

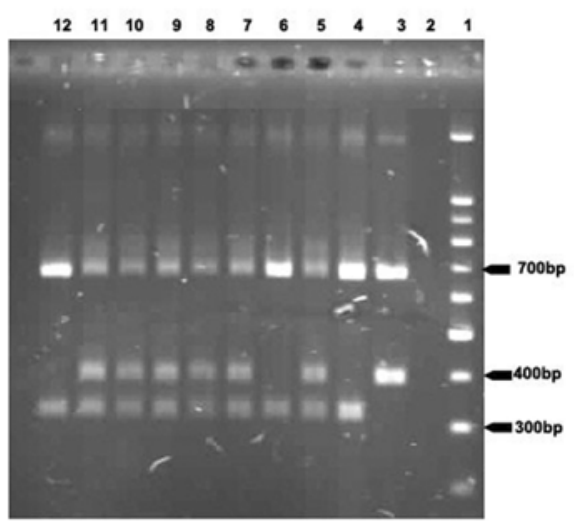

Table 2. Comparison of direct tissue blot immunoassay (DTBIA), enzyme-linked immunosorbent assay (ELISA), and reverse transcription-polymerase chain reaction (RT-PCR) for detection and isolate differentiation of Citrus tristeza virus (CTV)

\begin{tabular}{|c|c|c|c|c|c|c|c|c|c|c|}
\hline \multirow[b]{2}{*}{ Plant } & \multicolumn{3}{|c|}{ DTBIA } & \multicolumn{3}{|c|}{ ELISA } & \multicolumn{4}{|c|}{ RT-PCR } \\
\hline & $17 \mathrm{G11}^{\mathrm{a}}$ & MCA13 & Comment $^{\mathrm{b}}$ & 17G11 & MCA13 & Comment & 672 bp & 392 bp & 320 bp & Comment \\
\hline SSO-1 & + & - & M & + & - & $\mathrm{M}$ & + & + & - & M \\
\hline SSO-2 & + & + & $\mathrm{S}$ & + & $+/-$ & WS & + & + & + & $M \& S$ \\
\hline SSO-3 & + & - & M & + & - & M & + & - & + & S \\
\hline SSO-4 & + & - & M & + & - & M & + & + & - & M \\
\hline SSO-5 & + & - & $\mathrm{M}$ & + & - & M & + & + & - & M \\
\hline SSO-6 & + & - & M & + & - & M & + & + & - & M \\
\hline SSO-7 & + & + & $\mathrm{S}$ & + & - & M & + & + & + & $M \& S$ \\
\hline SSO-8 & + & + & $\mathrm{S}$ & + & + & S & + & - & + & S \\
\hline SSO-9 & + & + & $\mathrm{S}$ & + & + & $\mathrm{S}$ & + & + & + & $M \& S$ \\
\hline SSO-10 & + & + & $\mathrm{S}$ & + & + & $\mathrm{S}$ & + & + & + & $M \& S$ \\
\hline SSO-11 & + & + & $\mathrm{S}$ & + & + & $\mathrm{S}$ & + & + & + & $M \& S$ \\
\hline SSO-12 & + & + & $\mathrm{S}$ & + & + & $\mathrm{S}$ & + & + & + & $M \& S$ \\
\hline SSO-13 & + & + & $\mathrm{S}$ & + & + & $\mathrm{S}$ & + & + & + & $M \& S$ \\
\hline SSO-14 & + & + & $\mathrm{S}$ & + & + & $\mathrm{S}$ & + & - & + & S \\
\hline GF-1 & + & $+1-$ & WS & + & + & $\mathrm{S}$ & + & - & + & $\mathrm{S}$ \\
\hline GF-2 & + & - & $\mathrm{M}$ & + & - & M & + & + & - & M \\
\hline GF-3 & + & + & $\mathrm{S}$ & + & + & $\mathrm{S}$ & + & - & + & $\mathrm{S}$ \\
\hline $\mathrm{GF}-4$ & + & + & $\mathrm{S}$ & + & + & $\mathrm{S}$ & + & - & + & S \\
\hline GF-5 & + & - & $\mathrm{M}$ & + & - & $\mathrm{M}$ & + & + & + & $M \& S$ \\
\hline GF-6 & - & - & UD & - & - & UD & + & - & + & S \\
\hline GF-7 & + & - & M & + & - & M & + & + & - & $\mathrm{M}$ \\
\hline
\end{tabular}

a $+=$ positive reaction, $-=$ negative reaction, $+/-=$ uncertain reaction.

${ }^{\mathrm{b}} \mathrm{M}=\mathrm{T}_{30}$-like, $\mathrm{S}=\mathrm{T}_{36}$-like, $\mathrm{WS}=$ unidentified, $\mathrm{UD}=$ undetected. 
nal primers were the same as those of Cevik et al. (8), but the two terminal primers were modified. The 5 '-terminus of primers $\mathrm{HCP}_{1}$ and $\mathrm{HCP}_{2}$ contained no enzyme digestion site, and the length of primer $\mathrm{HCP}_{1}$ was changed so that all four primers had the same melting point temperature (Table 1). These primers were used to successfully detect decline-inducing and non-decline-inducing isolates of CTV in both sweet orange and grapefruit trees in the field. There was not a good correlation between field symptoms and detection of decline-inducing CTV by any method. Four SSO plants with declining symptoms were infected only with non-declineinducing isolates by ELISA, DTBIA, and RT-PCR. Likewise, three GF plants with non-declining symptoms were infected with decline-inducing isolates. This can be explained by the observations that the SSO trees had significant citrus root weevil damage and that grapefruit on sour orange rootstock can be infected with declineinducing CTV for at least 6 years without going into decline (C. A. Powell, unpublished).

An important distinction of perennial crops is their ability to accumulate multiple pathogens over the years of cultivation, including multiple closteroviruses. There are numerous, genetically distinct isolates of CTV in citrus. They may be present in an infected plant separately or in mixed infections, and they provide an ideal reservoir of infection $(1,16)$. Often up to $25 \%$ of the samples were infected with more than one isolate of CTV (22). Tests of 21 infected field samples with RT-PCR showed that 8 samples contained mixed infections (Table 2). The result also indicated that this method is not only able to detect and differentiate the declineinducing and non-decline-inducing isolates of CTV, but also to detect both isolate types in both single grapefruit and sweet orange trees. It is suggested that the method might be used for field diagnosis of CTV, to evaluate cross-protection, and to select non-decline-inducing isolates useful for cross-protection from healthy appearing trees in groves severely affected by CTV.

It has been demonstrated that sweet orange and grapefruit plants that were infected with both decline-inducing and nondecline-inducing isolates of CTV may carry the decline-inducing isolates at a concentration or distribution that eluded detection by ELISA with MCA13 (25). Other studies have also reported that PCR methods are more sensitive than ELISA for the detection of CTV and Cucumber mosaic virus (CMV) $(8,14)$. We have confirmed that the RT-PCR method is more sensitive than ELISA for the field diagnosis of CTV. RT-PCR results showed that some samples that were MCA13-negative in ELISA and/or DTBIA were infected with decline-inducing or a mixture of de- cline-inducing and non-decline-inducing isolates of CTV (Table 2, samples SSO-3, SSO-7, GF-5, and GF-6).

The total nucleic acid extract, prepared from very small quantities (about $250 \mathrm{mg}$ ) of stems of citrus, can be used as the template for RT-PCR. In our extraction procedure of nucleic acid, stems were placed in a canister and pulverized with liquid nitrogen using a KLECO Model 4200 Pulverizer. It is less time-consuming and laborintensive than pulverizing stems by mortar and pestle. The drawback of RT-PCR is that it is more expensive than ELISA and DTBIA. However, it is easy, rapid, and can be used for quarantine and budwood certification programs, which need reliable, sensitive, and rapid techniques.

\section{ACKNOWLEDGMENTS}

We thank B. Baclaski and R. Shatter for sharing their lab equipment.

\section{LITERATURE CITED}

1. Albiach-Marti, M. R., Guerri, J., Hermoso de Mendoza, A., Laigret, F., Ballester-Olmos, J. F., and Moreno, P. 2000. Aphid-transmission alters the genomic and defective RNA populations of Citrus tristeza virus isolates. Phytopathology 90:134-138.

2. Albiach-Marti, M. R., Mawassi, M., Gowda, S., Satyanarayana, T., Hilf, M. E., Shanker, S., Almira, E. C., Vives, M. C., Lopez, C., Guerri, J., Flores, R., Moreno, P., Garnsey, S. M., and Dawson, W. O. 2000. Sequences of Citrus tristeza virus separated in time and space are essentially identical. J. Virol. 74:6856-6865.

3. Bar-Joseph, M., Garnsey, S. M., Gonsalves, D., Moscovitez, M., Purcifull, D. E., Clark, M. F., and Loebenstein, D. 1979. The use of enzyme-linked immunosorbent assay for the detection of citrus tristeza virus. Phytopathology 69:190-194.

4. Bar-Joseph, M., and Lee, R. F. 1989. Citrus tristeza virus. CMI/AAB Descriptions of Plant Viruses (Assoc. Appl. Biol. Inst. Hortic. Res., Wellesbourne, Warwick, UK). Vol. 353.

5. Brlansky, R. H., Garnsey, S. M., Lee, R. F., and Purcifull, D. E. 1984. Application of citrus tristeza virus antisera in labeled antibody, immunoelectron microscopical, and sodium dodecyl sulfate-immunodiffusion tests. Pages 337-342 in: Proc. Conf. IOCV, 9th IOCV, Riverside, CA.

6. Brlansky, R. H., Lee, R. F., and Garnsey, S. M. 1988. In situ immunofluorescence for the detection of citrus tristeza virus inclusion bodies. Plant Dis. 72:1039-1041.

7. Cambra, M., Camarasa, E., Gorris, M. T., Garnsey, S. M., and Carbonell, E. 1991. Comparison of different immunosorbent assays for citrus tristeza virus (CTV) using CTV-specific monoclonal and polyclonal antibodies. Pages 38-45 in: Proc. Conf. IOCV, 11th IOCV, Riverside, $\mathrm{CA}$.

8. Cevik, B., Pappu, S S., Pappu, H. R., Benscher, D., Irey, M., Lee, R. F., and Niblett, C. L. 1996. Application of bi-directional PCR to citrus tristeza virus: Detection and strain differentiation. Pages 17-24 in: Proc. Conf. IOCV, 13th IOCV, Riverside, CA.

9. Garnsey, S. M., Gonsalves, D., and Purcifull, D. E. 1979. Rapid diagnosis of citrus tristeza virus infections by sodium dodecyl sulfateimmunodiffusion procedures. Phytopathology 69:88-95.

10. Garnsey, S. M., Gumpf, D. J., Roistacher, C. N., Civerolo, E. L., Lee, R. F., Yokomi, R. K., and Bar-Joseph, M. 1987. Toward a standard- ized evaluation of the biological properties of citrus tristeza virus. Phytophylactica 19:151157.

11. Garnsey, S. M., Permar, T. A., Cambra, M. and Henderson, C. T. 1993. Direct tissue blot immunoassay (DTBIA) for detection of citrus tristeza virus (CTV). Pages 39-50 in: Proc. Conf. IOCV, 12th IOCV, Riverside, CA.

12. Gillings, M., Broadbent, P., Indsto, J., and Lee, R. F. 1993. Characterization of isolates and strains of citrus tristeza closterovirus using restriction analysis of the coat protein amplified by the polymerase chain reaction. J. Virol. Methods 44:305-317.

13. Guerri, J., Moreno, P., and Lee, R. F. 1990. Identification of citrus tristeza virus strains by peptide maps of virion coat protein. Phytopathology 80:692-698

14. Hu, J. S., Li, H. P., Barry, K., and Wang, M. 1995. Comparison of dot blot, ELISA, and RTPCR assays for detection of two cucumber mosaic virus isolates infecting banana in Hawaii. Plant Dis. 79:902-906.

15. Hung, T. H., Wu, M. L., and Su, H. J. 2000. A rapid method based on the one-step reverse transcriptase-polymerase chain reaction (RTPCR) technique for detection of different strains of Citrus tristeza virus. J. Phytopathol. 148:469-475.

16. Karasev, A. V. 2000. Genetic diversity and evolution of closterviruses. Annu. Rev. Phytopathol. 38:293-324.

17. Karasev, A. V., Boyko, V. P., Gowda, S., Nikolaeva, O. V., Hilf, M. E., Koonin, E. V., Niblett, C. L., Cline, K., Gumpf, D. J., Lee, R. F., Garnsey, S. M., Lewandowski, D. J., and Dawson, W. O. 1995. Complete sequence of the citrus tristeza virus RNA genome. Virology 208:511-520.

18. Lee, R. F., Calvert, L. A., Nagel, J., and Hubbard, J. D. 1988. Citrus tristeza virus: Characterization of coat proteins. Phytopathology 78:1221-1226.

19. Lin, Y., Rundell, P. A., Xie, L., and Powell, C. A. 2000. In situ immunoassay for detection of citrus tristeza virus. Plant Dis. 84:937-940.

20. Mehta, P., Brlansky, R. H., Gowda, S., and Yokomi, R. K. 1997. Reverse-transcription polymerase chain reaction detection of citrus tristeza virus in aphids. Plant Dis. 81:10661069.

21. Miyakawa, T. 1987. Strains of citrus tristeza virus in Japan. Phytophylactica 19:134-144.

22. Niblett, C. L., Genc, H., Cevik, B., Halbert, S. Brown, L., Nolasco, G., Bonacalza, B., Manjunath, K. L., Febres, V. J., Pappu, H. R., and Lee, R. F. 2000. Progress on strain differentiation of citrus tristeza virus and its application to the epidemiology of citrus tristeza disease. Virus Res. 71:97-106.

23. Pappu, H. R., Pappu, S. S., Lee, R. F., Cambra M., Moreno, P., Garnsey, S. M., and Niblett, C. L. 1994. The molecular basis for the antigenic diversity of citrus tristeza virus: Implication for virus detection. Proc. Fla. State. Hortic. Soc. 107:8-12.

24. Pappu, H. R., Pappu, S. S., Manjunath, K. L., Lee, R. F., and Niblett, C. L. 1993. Molecular characterization of a structural epitope that is largely conserved among severe isolates of a plant virus. Proc. Natl. Acad. Sci. USA 90:3641-3644.

25. Powell, C. A., Pelosi, R. R., and Rundell, P. A 2003. Prevalence of Citrus tristeza virus in Florida citrus nurseries and scion groves. HortScience 38:244-245.

26. Rocha-Pena, M. A., and Lee, R. F. 1991. Serological technique for detection of citrus tristeza virus. J. Virol. Methods 34:311-331.

27. Rocha-Pena, M. A., Lee, R. F., Lastra, R., Niblett, C. L., Ochoa-Corona, F. M., Garnsey, S. M., and Yokomi, R. K. 1995. Citrus tristeza virus and its aphid vector Toxoptera citricida. Plant Dis. 79:437-445. 
28. Rocha-Pena, M. A., Lee, R. F., and Niblett, C. L. 1991. Development of a dot-immuno binding assay for detection of citrus tristeza virus. J. Virol. Methods 34:297-309.

29. Rocha-Pena, M. A., Lee, R. F., Permar, T. A., Yokomi, R. K., and Garnsey, S. M. 1991. Use of enzyme-linked immunosorbent and dotimmunobinding assay to evaluate two mild strains cross protection experiments after challenge with a severe citrus tristeza virus isolate. Pages 93-102 in: Proc. Conf. IOCV, 11th IOCV, Riverside, CA.
30. Rubio, L., Ayllon, M. A., Guerri, J., Pappu, H R., Niblett, C. L., and Moreno, P. 1996. Differentiation of citrus tristeza virus (CTV) isolates by single-strand conformation polymorphism analysis of the coat protein gene. Ann. Appl. Biol. 129:479-489. 